\title{
РАЗМИСАА ЗА ЕТИКАТА НА СВЕТИНАУМОВОТО ЧУДОТВОРСТВО И НА НАРОДНИОТ ДУХ
}

\section{Кратка содржина}

Поаѓајќи од тоа дека не е доволно само да се тргаш од злото, туку дека суитината е тргајќ се од злото и да го тргнеш злото, а тоа го можеш само кога ќе почнеш добро да постапуваш, долично на човека како Божји храм - станува јасно зошто и како една етика на практично дејствуване, како што тоа е случајот со свети Климент, прераснува во една етика на духовно обликуване на просторот и луѓémо каде што се живее. Дека на свети Климент му поа́а од рака доказ е и случајот со свети Наум, па затоа не треба да нѐ чуди што освен што е прогласен за светеи, многу почесто се нарекува и "чудотвореи,".

"Чудотворец," може да се стане ако одредена група, одредени "исиеленија“, ги прогласи како Божјо чудо, или кога, разбирајќ ја етиката на свочте учители Кирил и Методиј, но пред сѐ Климент, тие ви стануваат појдовница за создаватье простор во кој човекот ке дојде до она што го прави човек - духовен простор во кој тој ќе се најде себе си отворајќи се за, Духот. Притоа, не нарушувајќ го идентитетот, ниту Божји, ниту монашки, ниту канонски, и отворајќи простор за градењье цркви на чии sидови ќе се даде простор за антицииативно коментиратье на светот, но и простор за оние кои ке влезат во нив гледајки ги фреските, иконите, слушајки го Божјото слово, да дојдат до себе како храм Божји, но универзално етички граден - е резултатот кој ја потврдува оваа етика на чудотворство, етика на народниот дух. Ваков етички квалификатив на Наумовиот животен резултат е и предмет на анализа на овој текст.

Клучни зборови: ЧУДОТВОРСТВО, ЧУДОТВОРЕЦ, ЧУДОТВОРНО, СВЕТЕЦ, ЕТИКА

\section{Вовед}

Ако свети Кдимент Охридски остана запаметен во колективната народна меморија преку неговата просветителска дејност, преку подучувањето на народот не само на пишување и читање, туку и на други практички работи, дикот и делото на свети Наум останаа врежани во таа меморија како за учител, просветител, но најмногу чудотворец кој има моќ да лекува и за време на животот и по смртта од најраздични болести и луѓе од разни вероисповеди. Но од овој аспект на анадиза, можеби и уште поважно, свети Наум остана запаметен и по заштитата на манастирот, не само како место за описменување и пренесување на осознаеното, туку најмногу по наградување на оние што со добра мисла доаѓале во кругот на манастирот. 
Имено, поаѓајќи од тоа дека не е доволно само да се тргаш од злото, туку дека суштината е тргајќи се од здото и да го тргнеш злото, а тоа го можеш само кога ќе почнеш добро да постапуваш, долично на човека како Божји храм - станува јасно зошто и како една етика на практичко дејствување, како што тоа е случајот со свети Климент, прераснува во една етика на духовно обликување на просторот и луѓето каде што се живее. Дека на свети Климент тоа му поаѓа од рака доказ е и тезата на свети Наум Охридски Чудотворец - до духовност во целосна смисла на зборот во неговото сеопфатно значење може да се дојде само доколку претходно се создадат услови кои човекот, и како тело и како суштество, ќе го донесат до свеста за неговата должност спрема Бога. А тоа може да биде само доколку не само со материјалите услови, туку и со духовниот простор, се овозможи секој од нас на свој начин и сразмерно на своите потреби и можности, да се пронајде во Божјите храмови или на sидовите кои се насликани.

\section{Био/библио забелешка}

Наспроти оскудните информации за животот на свети Наум, а уште повеќе и поради фактот што неговиот живот бид во многу нешта во сенка на животот на свети Климент, сепак, согласно располождивите извори (двете словенски житија ${ }^{1}$, грчкото житие ${ }^{2}$, Панонските легенди и Пространото Климентово житие) можно е да се направи барем една депумна реконструкција на животната врвица на овој просветител, духовник и мисионер, еден од основоположниците на словенската и македонската писменост и просвета.

Според преданијата, од кои „најкарактеристично е преданието „Свети Климент Охридски“ (Антиќ, 1982: 25-26), кое во својата основа го има житието на Теофилакт Охридски, свети Наум е роден во првата половина на IX век, израснал во Мизија, „воспитан од благородните негови (родители), сето благородство и богатство го сметаше за плева..." (Миловска, 1996: 87). Како еден од Петточислениците и најбдиски ученици кои соработувале со словенски рамноапостоли Кирид и Методиј, свети Наум уште

\footnotetext{
1 Првото, постарото, настанало во првата половина на $X$ век, а е познато според препис од XV век - „Месец декември, ден дваесет и трети, спомен на преподобниот и богоносен отец наш Наум, великиот чудотворец, во Аивание Деволско, близу до Охрид“. Второто словенско Наумово житие е поново - „Месец декември (ден) дваесет и трети, спомен на преподобниот отец наш Наум“. Тоа е познато според препис настанат во XVI век. Според Добрила Миловска, Македонски житија IX XVIII век, Скопје: Табернакул, 1996, стр. 11. Подетално, Михајло Георгиевски, Македонски светици, Скопје: Култура, 1997, стр. 67.

2 Постои мислење дека второто словенско Наумово житие е превод од грчки јазик или компилација од грчки извори. Според Йорданъ Ивановъ, Български старини изъ Македония, София: Бъдгарско книжовно дружество, 1931, стр. 240.
} 
од својата младост верно ги следел учителите во Моравија и Панонија, каде што во текот на многу години (863 - 885) им го проповедал Божјото слово на словенските народи на нивниот роден јазик. Истите ги обучувад во писменоста, ги распространувал богослужебните книги кои рамноапостолните браќа ги превеле од старогрчки јазик на словенски, а во 868 година потврдата на истото стигнала и од Рим, кога папата Адриан II (867 - 872) го признал делото на словенските учители како богоугодно, ги осветил словенските книги и благословия да се служи дитургија на словенски јазик, а свети Наум, меѓу останатите, бил ракоположен за презвитер. (Миловска, 1996: 88)

По смртта на словенскиот учител Методиј во 885 година, во Моравија настанала жестока борба меѓу учениците на солунските браќа Кирил и Методиј и германските свештеници. Проповедниците биле фрлени во темница, приковани во окови, подложени на мачење, продавани како робови во Венеција, а некои и брутално протерани преку граница. И свети Наум е меѓу протераните свети проповедници, кои движени од Божјата Промисла стигнале до Дунав каде што се разделиле по групи. Некои од нив тргнале кон Мизија, други во Далмација и Дакија, „Божјото слово умножувајќи го насекаде стократно“ (Миловска, 1996: 89). Свети Наум заедно со светите Климент и Ангелариј отпатувале во Бугарија, каде бугарски цар Борис ги примил со радост бидејќи имал потреба од такви ученици, т.е. сакал да го прошири своето влијание во западните делови, поточно во Македонија (История македонского народа, 1986: 21). Тој го испратид свети Климент како учител во Македонија, во Кутмичевица (некаде меѓу Охрид, Девол и Главеница), отворајќи ја страницата на Охридскиот книжевен центар, а свети Наум останал во престолнината Плиска, да организира словенски просветен и книжевен центар. Иако не во престолнината Плиска, каде што била резиденцијата на византискиот архиепископ на Бугарија, туку во блискиот словенски град Преслав, свети Наум ја отворил вратата на Преславскиот книжевен центар 3 , учителствувајќи и проповедајќи во манастирот изграден во чест на свети Пантелемон, близу Преслав $(886-893)^{4}$.

Во 893 година, на црковно-народен собор, кога неговиот „брат“ Климент бил ракоположен за словенски епископ во Велика, на неговото учителско место во Кутмичевица бугарскиот цар Симеон го испратил Наум. Така, „Наум и Климент дојдоа во пределите илирски и лихнидски“ (Миловска, 1996: 89). Тука свети Наум го возглавил просветителското дело, кое седум години го извршувале заедно со свети Климент (Миневски, 2015: 24), односно во Македонија, во Охридската книжевна школа, притоа издигнувајќи се како втор главен претставник во Охридскиот книжевен центар.

${ }_{3}^{3}$ Додека Ангелариј во меѓувреме починал.

4 Затоа и се смета за еден од основачите на Преславската книжевна школа. 
Познато е дека се занимавал со литературна дејност, иако за жал денес сѐ уште не е позната ниту една творба потпишана со неговото име. Можеби од скромност или од друга причина, никаде не си го ставил името, иако според зборовите на Константин Брегалнички се вели дека поттик да го напише „Поучителното евангелие“ му дал Наум. (Поленаковиќ, 2007: 344) Сепак, она по што оставил длабока трага е неуморниот труд (задно со свети Климент) над преводот на Светото писмо и останатите црковни книги од грчки јазик на словенски јазик, поради што биле наречени и „новите Мојсеј и Арон. ${ }^{\text {” }}$

И додека во Охрид свети Климент ги вршел светителските/епископските трудови, свети Наум, како мудар учител, чудотворец ${ }^{6}$ и модитвеник, околу кого се собрале многу монаси (Миневски, 2015: 24) - изградил манастир во чест на светите Архангели (денешен свети Наум), на јужниот брег на Охридското Езеро, кој станал извор на благочестие ${ }^{7}$ и прибежиште за бедните. Во манастирот што тој го основал и кој е познат меѓу народот како манастир на свети Наум, престојувал десет години завршувајќи го својот земен 80-годишен пат и упокојувајќи се на 23 декември 910 година. Таму и сега почиваат неговите свети мошти, иекувајќи ${ }^{8}$ - со силата на Хрис-

${ }^{5}$ Во грчкот Синаксар свети Климент и свети Наум се нарекуваат „нови Мојсеј и Арон“ и за нив се раскажува ова чудо: „еретиците во Германија ги оковале и ги фрдиле во затвор. Но со силата Божја затворот се затресол, оковите од нив испаднале, вратата на затворот се отворила и тие слободно си излегле“.

${ }^{6}$ Познат е и како чудотворец бидејќи се зборува дека направил многу чуда, а некои од нив се претставени и на фреските од неговиот манастир како онаа на која е претставен „како ја впрегнал мечката да го влече плугот наместо волот што го изела“. Импресионираат и другите сцени од животот и чудата на свети Наум кои се насликани во втората зона од Наумовиот гробен параклис: „Вкочанување на монахот што се обидел да го украде тедото на свети Наум од неговиот гроб“, „Декување на нервно заболени“, „Крадец на коњ кого зората го затече пред вратите на манастирската црква“ и „Ведрото остава вдлабнатина во каменот“. Подетално Цветан Грозданов, Свети Наум Охридски, МАНУ \& Матица Македонска, Скопје, 2015, а особено Стојан Ристески, Иегенди и преданија за свети Наум, Скопје: Институт за фолклор „Марко Цепенков“, 1990, каде се објавени 120 легенди.

7 Според првото житие на свети Наум, манастирот бил изграден во 900 година, според второто во 905 година. Овој манастир уште во времето на свети Наум обилувал со богат фонд на книги, а подоцна низ вековите станал вистинско хранидиште на словенски книги и ракописи. Така, овој манастир како и манастирот на свети Климент можат да се вбројат меѓ првите македонски манастири што распоиагале со богати манастирски библиотеки.

${ }^{8}$ Манастирот најповеќе се афирмирал како лечилиште со исцелување болни од многу болести, посебно од душевни болести. За тоа придонесло верувањето во исцелителната моќ на светите мошти на светителот. Има поголем број преданија што раскажуваат за лечење душевно болни од страна на светителот, односно дека во манастирот долго време постоела и душевна болница. Ристески, Аегенди и преданија за свети Наум. 
товата благодат - душевни слабости и болести (Митревски, 1983: 139), лекувајќи и за време на животот и по смртта, лекувајќи од најраздични болести и луѓе од разни вероисповедия односно сите што искрено и со верба му се обраќаат без раздика на вера и народност.

\section{Етиката на чудотворството}

Говорејќи за свети Наум Чудотворец, неговото дело и етика, најпрво мораме да се вратиме и потсетиме на светикдиментовата етика која во принцип можеме да ја дефинираме и како етика на философијата на образованието, како начин да се дојде и до оние делови од нашето суштество, нашето постоење, нашата свест, но и до дедовите на она во кортексот за кои не секогаш имаме потполно рационално, научно или егзактно објаснување. Со други зборови, токму со своето конкретно дејствување свети Климент, којшто поголемиот дел од својот живот го посвети на истражување на човечкото тело и начините на неговото одржување во состојба во која телото ослободено од своите слабости ќе биде посветено на создавање, што ги оспособува учениците и следбениците барем малку да го продолжат она што тој го започна - на своите наследници им создаде не само конкретни резултати, туку им всади и одредени начини на размислување за човекот не само како Божји дар, туку пред сѐ како нешто за што треба да се размислува за да се дојде до Бога. Всушност се работи за воспоставување етика која поаѓ од фактите дека не може да постои Бог, ниту пак до Него да се дојде, а уште помалку да се биде Негов храм, доколку човекот пред сѐ не се отвори во себе си за себе, пред Бога за Бога. ${ }^{10}$

Вака сфатена, применувана и со резултат докажана, Светикдиментовата етика покажува и дека до духовност во целосна смисла на зборот, во неговото сеопфатно значење, може да се дојде само доколку претходно се создадат услови кои човекот, и како тедо и како суштество, ќе го донесат до свеста за неговата должност спрема Бога. Но не само спрема Бога за да се исполни неговата накана за нас, туку услови кои ќе го доведат до свеста за должноста спрема Бога да се биде човек на човека! А тоа може да биде само доколку не само со материјалите услови, туку и со духовниот простор, се овозможи секој од нас на свој начин и сразмерно на своите потреби

\footnotetext{
9 Дека припадници на други вери го почитувале светителот и манастирот се зборува во голем број на преданија и легенди каде што се вели: „Оваа света институција стекна голем углед и чест и кај друговерци, а особено кај Отоманите Бекташи, кои не се знае од какви причини, ова светилиште го викаат „Сари Салтик баба“ што преведено од турски значело жолтобрадиот татко. Според едно предание, еднаш кога дошие на гробот на свети Наум, неколку Турци замолиле некој од поупатените да им ги објасни диковите од фреските. Кога тој што им ги објаснувал рекол: „Овој е свети Наум“, тие радосно извикале: „А тој е нашиот татко“.

${ }^{10} \mathrm{O}$ дносно, обоготворувањето на човекот има пред сѐ етичка димензија, а не само есхатолошка димензија - да се биде христијанин значи да се биде етичен!
} 
и можности, да се пронајде во Божјите храмови иди на sидовите кои се насликани, како што се насликани во црквите на град Охрид каде што свети Наум најмногу создаваше простор преку конкретно дејствување. ${ }^{11}$

Но, сепак, ова не е единствениот раздог што свети Наум станал чудотворец и светец, а уште помалку објаснува зошто е прогласен за таков. Имено, светец можел да стане и со тоа што започнал или овозможил изградба на огромен број на цркви донесувајќи голем број на фрескописци и иконописци, кои со своите дела, давајќи душа на внатрешноста на истите, дале душа и на човечката внатрешност. Со тоа, во секој случај, ако не пред Бога, тогаш пред човештвото, го заслужил името на светец, односно ја исполнил не само својата човечка - етичка обврска - сѐ свое на другите да им даде, туку и ненарушувајќи ги владејачките канони, ги удоволил и условите на црковните власти според кои се станува светец онаков каков што црквата бара, за да и понатаму може да ја остварува својата функција во услови во кои повеќе била контролор отколку создател или ослободител. ${ }^{12}$

Дека тоа е така, нема сомнение исто како што нема сомневање ниту во тоа дека претходното не го прави да биде чудотворен или чудотворец, со што ова прашање сѐ уште останува отворено. Имено, чудотворец може да се стане на два начина. Најчесто, така што некоја овластена група на беатификатори, одредени „исцелувања“ или „настани“ ги прогласува за Божјо чудо. Вториот е оној кога етиката на своите учители Кирил и Методиј, но пред сѐ Климент, станува основа за создавање простор во кој човекот ќе дојде до она што го чини човек - духовен простор во кој ќе се пронајде себе си, отворајќи се за Духот - како во случајот со свети Наум. (Темков, 1998: 80 - 97)

Ваков простор може да се отвори на повеќе начини. Но, она што сигурно го докажа Наум како „чудотворен“ е фактот што станувајќи еден од основачите и водечките луѓе на т.н. Охридска книжевна школа, попозната како „Прв словенски универзитет“, свесен за фактот дека пишаниот збор во тоа време не бил само привилегија на одреден слој и начин истиот тој слој да владее со луѓето, но воедно и незаобиколувајќи ги сознанијата дека светот се вреднува, прифаќа или одбива во зависност од тоа што во него гледаме - помеѓу останатото го основа и манастирот денес познат под името Свети Наум. Но да се основа и изгради манастир и со тоа се стане прв основач на манастир во овие предели, само по себе не е чудо затоа што надвор од секаков сомнеж е дека такви светилишта се градат ех nihilo како

${ }^{11}$ Имено, свети Наум остана запаметен, меѓу другото и по заштитата на манастирот, по наградувањето на оние што со добра мисла доаѓале во кругот на манастирот и казнувањето на оние што иделе со намера да направат некоја штета, да го испоганат објектот или да го навредат светителот.

12 За подлабок увид во тековните состојби може да се погдедне Блаже Ристовски, Портрети и процеси од македонската литературна и нацุионална историја 1, Скопје, Култура, 1989, стр. 25 - 46. 
Божјиот свет. Чудото е во тоа што, и тоа е она што во суштина го прави "чудотворен“ - направил спој, синтеза помеѓу вкоричениот Божји збор и насликаниот Божји збор по мера на човекот, онаков каков што е во време во кое сме, но не помалку и за она и оние кои доаѓаат. Што е уште поважно, сликарите на тие фрески и икони, токму поради тоа што работеле под закрила на човекот кој длабоко во себе сфатил дека само давајќи ја внатрешната слобода на идејата, па макар и формално спакувана, може да се говори не само за времето во кое истите настанале (фреските и иконите) (Грозданов, 2015: 215).

Имено, битен е и фактот дека тие овозможиле и на времето кое ги наследило и на луѓето кои ги оценувале, проценувале или осудувале, независно од своето гдедиште, сепак на крајот да спознаат дека постојат вредности кои не зависат од времето или материјалните услови, туку според просторот кој се отвора како дел од човековото живеење како Божјо суштество: не според волјата на Бог истиот да не се чувствува сам, туку како суштество кое само давајќи простор на другите во себе, отвора простор за себе во другите, а со тоа и простор за пат до Бога.

Токму вака сфаќајќи ја улогата на етиката на верување и дејствување, свети Наум, издигнувајќи се од етиката на свети Климент на едно друго духовно ниво - отворајќи простор за себеоткривање по пат на зборот и сликата од сфатеното за тоа што е она што би требало да биде Божји храм - го отвора патот и на оние кои доаѓаат, на „рамењата“ на претходните да стигнат/се издигнат до степен на кој тие пак понатаму ќе отвораат пат на другите. Со тоа се покажува и докажува етиката на чудотворност на свети Наум Охридски. Точно, токму ова е она што оваа етика ја прави чудотворна, а него чудотворен.

Токму ваквото втемелено постапување кое со претходно кажаното е докажано како етичко, доведува до она што како нијансирани зборови се провлекува до крајот на текстот, а тоа е „чудотворец“, „чудотворство“, „чудотворен“. Имено, за „чудотворци“ се именуваат иуѓето кои направиле чуда, а за „чудотворен“" се именува оној кој не направид чудо, туку предизвикал чудо кое посредно или непосредно му било пример или пак со своето дејствување овозможил на другите во себе да го откријат и реализираат таквиот тадент или таквата способност. Претходно кажаното нѐ воведува во она што го прави да биде „чудотворец“. Имено, доколку го сфатиме "чудотворен - чудопредизвикувачки“, т.е. овозможувач преку своето дејствување и наука за другите да го откријат во себе оној дел кој ќе им овозможи да направат чудо, т.е. прво да се вратат самите на себе си и се откријат како човечки суштества во кои Божјиот храм станува исто само тогаш кога во нив се отвора простор и за другите. Тоа воедно го прави и чудотворец затоа што токму на другите им овозможил да се откријат себе си, да се вратат на себе си како човечки суштества и со тоа преку нивното однесување кон другите покажат третман на човечки суштества. 
Значи, свети Наум прави чудо во околностите во кои дејствува! Имајќи ги предвид не само политичките околности, туку пред сѐ економските околности во кои работи, а особено знаејќи ги теолошко/канонските притисоци на кои бид издожен од Цариград, а кој сѐ уште бил под вдијание на поделбата пред и по Никеанските собори, неговиот начин на развивање на писменоста, уметноста, неимарството, отвория духовен простор во кој еден народ препознавајќи ги навистина реалните етички вредности, ќе се открие себе си како автохтоно и автономно суштество. Тоа е резултатот од неговата етика која и денес после толку векови се гледа без оглед на моменталното политизирање на философијата и филозофирачкото политиканство. Поточно, таквото етичко стојадиште на неговото практичко дејствување доведе и до свеста на една средина независно од дневните настани сепак да може да остане човечка, етички втемелена и свесна, независно од разноразни пропаганди за можна репродукција, т.е. покажа како може да се остане доследен на тезата дека не може да се создава наследство, ниту културно, ниту биолошко, доколку не се води сметка за капацитетот и можностите на просторот каде тоа се случува!

Ова последното не е со намера да се влезе во дневноподитичко филозофирање или политизација на философијата, туку пред и над сѐ, да се укаже на фактот дека луѓето како што се свети Климент и свети Наум станале она што се - светци, не затоа што ги задоволиле условите на „конкурсот" за беатификација. Тие станале тоа во наследството и на народот и на културата токму поради тоа што независно од политички предизвиканите теолошко/канонски објаснувања, пред и над сѐ, покажале со својата практична дејност дека поаѓаат од човекот за да му овозможат не само да се врати на себе си поради себе, туку и за другите и поради другите. Тоа го правеле и за да му овозможат, покрај останатото не само да живее во согласност со Божјиот збор, туку живееки́ така да се ослободи од потребата за посредување помеѓу него и Бога, канонот и толкувањето, а кои не така ретко биле главно причини за поделбите, како што била онаа во 1054 година.

\section{Наместо заклучок...}

Споменувањето на наметнувањето и толкувањето на начинот на кој ќе се продолжува видот не е затоа што со тоа се сака да се влезе во некакви полемики со владејачките теолошки иди канонски тодкувања на функциите на човечкото постоење на земјата. Имено, говорејќи за свети Наум како чудотворен, токму поради тоа што на многумина им дал простор сликајќи фрески да го воведат човекот како мерило за разбирање на Божјата накана - нему му тргнало од рака да отвори простор од кој сите имале бенефит, а што е уште побитно, од кој простор сите можат ослободени од стравот дека ќе влезат во конфликт со толкувањето на Бога, да дојдат до себе си и така да се препорачаат Нему. 
Поедноставено, токму со вака етички мотивираното постапување и отворање на простор за другите, свети Наум успева посредно да создаде една свест во рамките на една заедница, која со текот на времето дораснала до свеста за себе си како ентитет. Независно од тоа дали ќе ги следиме или не канонските напатствија, сепак ќе можеме да се одржиме и продолжиме докодку од предоченото, од понуденото на увид, од насликаното и напишаното како начини на толкување на Божјите зборови, се разберат две работи:

1. ДА, ние сме Божји суштества!; ДА, ние сме тука за да ја продолжиме неговата накана и истата ја овозможиме во нејзината реадизација;

2. Но пред сѐ, тука сме затоа што сме научиле, што свесно, што несвесно, да постоиме не според протолкуваната Божја мера, туку според насетуваната мера на природата на стварите која ни вели дека ќе бидеме во согласност со Бога и со самите себе си и со нам предложената ни етика, а најмногу во меѓусебна согласност и разбирање, доколку сме во состојба да го продолжуваме родот и со тоа не го загрозуваме опстанокот на видот.

До крај изведен ваквиот став, во суштина, значи дека за етиката на чудотворството на свети Наум Охридски може да се говори не само како за етика на една вера со последица описменување и просветителство на еден иден народ и една идна нација, туку пред сѐ како за етика која овозможува да се сфати дека независно од името на заедницата, останува човекот кој му припаѓа на човештвото само докодку со своето постоење и продолжување не се загрозува истото. Иако можеби е помалку невообичаено ова тврдење, сепак доколку се направи конкретна паралела меѓу философијата и етиката на свети Наум и она што подоцна се нарекува за „Ренесанса на философијата“, лесно ќе се воочи едно заедништво во кое независно од функцијата на зборовите потпишани од канонот иди сликите во име на канонот, сепак стои фактот дека и во тие зборови и на тие слики се препознава човекот како крајна цел на создаденото. Односно, треба да се истакне дека, не нарушувајќи го идентитетот, ниту Божји, ниту монашки, ниту канонски, и отворајќи простор во кој градејќи цркви на чиишто ьидови ќе даде простор на антиципативното коментирање и етичко насочување кон светот, но и простор на оние кои ќе влезат во него да ги гледаат иконите, фреските, слушајќи го Божјото слово, да дојдат до себе како храм Божји, но универзално етички граден - неговата етика е потврдена со резултатот како етика на чудотворството, а конкретниот доказ може да се согледа во создадениот култ кон неговата дичност која зрачела на поширок простор не само во охридскиот крај, туку и во преспанскиот, па дури до Корча, каде што манастирот имал свои имоти, а култот кон свети Наум бил раширен и во Унгарија и Романија каде што имало иселеници од овие краишта. 


\section{Питература:}

Антиќ, Стојчевска, Вера (1982). Климент и Наум Охридски во народната традиција. Скопје: Наша книга.

БАТАЛДЕН, К. Стивен (1997). Преиспитуваюе на традицијата. Скопје: Култура.

ВРАЖИНОвСКИ, Танас (1999). Народна традиција, религија и култура. Скопје: Матица македонска.

ГЕОРГИЕВСКИ, Михајло (1997). Македонски светции. Скопје: Култура.

ГРОЗдАНОВ, Цветан (2015). Свети Наум Охридски. Скопје: МАНУ \& Матица македонска.

ЗИЗИУлАС, Д. Јован (1998). Од маска до личност. Струмица: Манастир Света Богородица Елеуса.

ИвАнОвъ, Йорданъ (1931). Български старини изъ Македония. София: Българско книжовно дружество.

ИСТОРИЯ МАКЕДОНСКОГО НАРОДА. Скопье: Македонская академия наук и искусств, 1986.

МиловскА, Добрила (1996). Македонски житија IX - XVIII век. Скопје: Табернакул.

МИНЕвСКИ, Блаже (2015). „Чудата и благодатите на свети Наум биле побројни од ввездите на небото“.Дневник, година XIX, број 5806, петок, 3 јули 2015.

МитРевСКИ, Трајан (1983). Православна христијанска апологетика - Религијата и нејзиното оправдуване (основно богословие). Скопје: Православен богословски факултет „Свети Климент Охридски“

ПОЛЕНАКОВИќ, Харалампие (2007). Избрани дела 1 - Во мугрите на словенската писменост. Скопје: Култура.

РИСтЕВСКИ, Блаже (1989). Портрети и процеси од македонската литературна и нациинална историја 1. Скопје: Култура.

РистескИ, Стојан (1990). Аегенди и преданија за свети Наум. Скопје: Институт за фолклор „Марко Цепенков“.

SREMAC, Srđan \& Sergej Beuk (2013). Svet i sveto. Beograd: Otačnik.

ТЕмков, Кирия (1998). Етика. Скопје: Епоха. 